\title{
A NATUREZA JURÍDICA DO PODER DE POLÍCIA É DISCRICIONÁRIA? ${ }^{1}$
}

\section{Marcia Andrea Bühring}

Mestre em Direito pela UFPR, Professora da UCS, Advogada.

\begin{abstract}
SUMÁRIO: Introdução; 1 O Poder de Polícia; 1.1 Origem e Evolução do Vocábulo; 1.2 Noções Apresentadas pela Doutrina e pela Legislação; 1.3 A Expressão Poder de Polícia; 1.4 Polícia Administrativa e Polícia Judiciária; 2 Discricionariedade; 2.1 Origem e Evolução; 2.2 Noções Apresentadas pela Doutrina; 2.3 Discricionariedade e Vinculação; 2.4 Discricionariedade e Arbitrariedade; 3 A Natureza Jurídica do Poder de Polícia é Discricionária? 3.1 Limites ao Poder de Polícia e à Discricionariedade; 3.2 A Natureza Jurídica do Poder de Polícia é Discricionária ou não? Considerações Finais; Referências Bibliográficas.
\end{abstract}

RESUMO: A natureza jurídica do poder de polícia é discricionária?

O poder de polícia, como limite ao exercício de direitos individuais, visa ao interesse público em benefício coletivo, que no direito brasileiro é usado como faculdade da Administração Pública, com a prevenção da polícia administrativa e a repressão da polícia judiciária. Os atos podem ser discricionários, com certa liberdade, segundo a conveniência e oportunidade, ou vinculados, sem essa margem, em obediência à lei.

A natureza jurídica do próprio poder de polícia não é discricionária; os atos sim, que são ora discricionários, ora vinculados.

ABSTRACT: Is the legal nature of the police power discretionary?

The police power as limit to the exercise of the individual rights aims the public interest for collective benefit, that in the Brazilian law is used as faculty of Public Administration, whit the administrative police prevention and the judicial police repression. The acts can be discretionary, with a certain liberty, according to the convenience and opportunity, or bonded acts, without that room, in obedience to the law. The legal nature of the police power itself is not discretionary, they acts are, that are sometimes discretionary, sometimes they are bonded.

\section{INTRODUÇÃO}

O tema relativo ao poder de polícia tem colocado em confronto dois aspectos: o cidadão, com o desejo de exercer seus direitos, e a Administração, com a incumbência de efetivar o exercício desses direitos, usando para isso seu poder de polícia. Todavia, esse poder encontra seu fundamento no princípio da predominância do interesse público sobre o particular, dando à Administração uma posição de supremacia em relação aos administrados.

Para atingir os objetivos desta pesquisa, propomo-nos a desenvolvê-la em três grandes pontos. No primeiro, faremos uma abordagem situando historicamente o poder

1 Monografia apresentada à disciplina Fundamentos do Direito Administrativo como requisito parcial à conclusão do Curso de Mestrado Interinstitucional em Direito, Universidade Federal do Paraná Universidade de Caxias do Sul. Orientadora: Prof ${ }^{a}$ Dra. ÂNGELA CÁSSIA COSTALDELLO. 
de polícia, apresentando as noções elaboradas ao longo dos anos, tanto na doutrina como na legislação, bem como a utilização dessa expressão, que tem causado muitos equívocos, além de trazer uma distinção entre a polícia administrativa e a polícia judiciária, temáticas essas fundamentais para a compreensão do próprio poder de polícia, tão presente hoje em nosso dia-a-dia.

No segundo ponto, verificar-se-á como é tratada a questão da discricionariedade, sua origem e evolução, e como aquela margem de liberdade que é concedida ao administrador pela lei opera no mundo jurídico. Referir-se-á também que as noções trazidas no direito pátrio guardam identidade conceitual com as noções oferecidas no direito comparado.

Far-se-á ainda um paralelo entre a discricionariedade e a vinculação, bem como entre a discricionariedade e a arbitrariedade, institutos esses que não podem ser confundidos.

No terceiro ponto, abordar-se-á a discussão doutrinária em torno do pressuposto das limitações tanto do poder de polícia como da discricionariedade e analisar-se-á a natureza jurídica do poder de polícia, se ela é discricionária ou não.

Considerando, ao final, alguns aspectos relevantes do tema abordado.

\section{O PODER DE POLÍCIA}

\subsection{Origem e evolução do vocábulo}

Para introduzirmos a importante temática, há que se fazer uma pequena referência, situando historicamente o poder de polícia, inicialmente na Antigüidade e Idade Média, em seguida dentro do que se determinou Estado de Polícia e, finalmente, dentro do Estado de Direito, abrangendo o Estado Liberal, o Social e o Democrático. Veja-se:

A palavra polícia vem do latim politia, pois largo era o seu conteúdo no direito antigo, ${ }^{2}$ e do grego politeo ou politeia, originariamente trazendo o sentido de organização política, de sistema de governo e governo, ${ }^{3}$ estando ligada, com o termo política, ao vocábulo polis, ou ainda politéia, no sentido de designar todas as atividades da cidadeestado, no entanto, sem manter qualquer relação com o sentido atual. ${ }^{4}$

$\mathrm{Na}$ Antigüidade, significou o ordenamento político, a Constituição do Estado ou cidade.

2 LIMA, R. C. Princípios de direito administrativo. 5. ed. São Paulo: Revista dos Tribunais, 1982, p. 107.

3 DE PLÁCIDO E SILVA. Vocabulário jurídico. Rio de Janeiro: Forense, v. III, J-P, 1999, p. 616.

4 DI PIETRO, M. S. Z. Direito administrativo. São Paulo: Atlas, 2000, p. 93-94. 
Já na Idade Média, foi usado inicialmente também nesse sentido amplo, embora no século XI tenha-se retirado da noção, o aspecto das relações internacionais. Assim, o poder de polícia, da forma como é conhecido hoje, já se encontrava "no âmbito das comunas européias, por seus administradores", saindo também lentamente "do âmbito da polícia as matérias relativas à justiça e às finanças". 5

Nesse período da Idade Média, "o príncipe era detentor do poder jus politiae, designando o necessário à ordem social em contraposição à ordem moral". Todavia, em fins do século XV, "o jus politiae volta a designar a atividade do Estado", compreendendo uma série de normas que eram postas pelo príncipe, estando fora do alcance dos Tribunais. ${ }^{6}$

Como primeira etapa do Estado Moderno, temos o Estado de Polícia, também chamado "Estado Iluminista", "Estado de despotismo esclarecido", polizeistaat, isto no século XVIII, ${ }^{7}$ cuja forma de governo era a monarquia absoluta com uma administração legalmente incondicionada, ou seja, com o poder concentrado nas mãos do rei, sem vínculo com as normas que limitassem a atividade, pois o direito era a vontade do rei, portanto, um poder ilimitado.

Em verdade, no século XVIII, a polícia designa "o total da atividade pública interna, sem a justiça e as finanças, e consiste na faculdade estatal de regular tudo o que se encontra no âmbito do Estado, sem exceção". E justamente esse momento de "apogeu" coincidiu com o que se chamou, no final da era absolutista, de Estado de polícia, Estado esse que, pela opressão, intrometia-se na vida dos indivíduos. ${ }^{8}$

Impunha, de forma ilimitada, as obrigações ou restrições às atividades dos particulares, ${ }^{9}$ submetendo os indivíduos ao Direito, mas não se sujeitando a ele. Reconheceu-se ao Soberano, em conseqüência, um poder ilimitado quanto aos fins a serem perseguidos e também quanto aos meios a serem empregados. ${ }^{10}$

Como segunda etapa do Estado Moderno, temos o Estado de Direito, com uma administração legalmente condicionada, cujo poder de polícia passou de ilimitado a limitado. Estado de Direito é o qual se subordina ao Direito, sujeitando-se às normas jurídicas que regulam sua ação.

5 MEDAUAR, O. Poder de polícia. In: Revista de Direito Administrativo, n. 199. Rio de Janeiro: RenovarFGV, p. 90-91, jan./mar. 1995; e MEDAUAR, O. Direito administrativo moderno. 4. ed. rev. atual. e ampl. São Paulo: Revista dos Tribunais, 2000, p. 387-389.

6 DI PIETRO. Direito administrativo..., p. 93-94.

7 CANOtilho, J. J. Gomes. Direito constitucional. 3. ed. reimp. Coimbra: Almedina, 1999, p. 87-88.

8 MEDAUAR. Poder de polícia..., p. 90-91; e MEDAUAR. Direito administrativo..., p. 387-389.

9 SUNDFELD, A. C. Fundamentos de direito público. São Paulo: Malheiros, 1992, p. 34.

10 GORDILlO, A. Princípios gerais de direito público. São Paulo: Revista dos Tribunais, 1977, p. 28. "Não cremos que se possa afirmar, pura e simplesmente, que não existia um Direito Público, como por exemplo disse MAYER, pois inclusive este princípio do poder ilimitado e as normas que dele emanaram constituem um certo ordenamento positivo; porém, ao menos pode-se sustentar que não existia, em absoluto, um ramo do conhecimento jurídico em torno do mesmo". 
Dentro do Estado de Direito temos um primeiro período, o Estado Liberal, que considerou a lei em sentido formal, entrando em cena ideais do liberalismo, desempenhando o Direito o papel de garantia às liberdades individuais, e tendo a lei como vontade geral. O poder de polícia tinha alcance limitado, sendo a polícia administrativa essencialmente uma polícia de segurança. ${ }^{11}$

Dessa passagem do Estado de Polícia para o Estado de Direito, aperfeiçoa-se a organização da cidade sob uma ação lícita da autoridade; todavia, o que marcou o advento da fase liberal foi o "princípio da limitação do poder", cujo cidadão podia opor seu direito ao poder do Estado, ao qual incumbia assegurar que "a liberdade de um não possa contrapor-se à liberdade de outro, na histórica definição do direito francês, de que 'a liberdade de cada cidadão termina onde começa a liberdade de outrem"”. Tornando-se isso possível a partir da ação ordenada do Estado para concretizar esse equilíbrio. ${ }^{12}$

Com a influência das idéias da Revolução Francesa e com a valorização de direitos individuais, o sentido de polícia restringiu-se e passou a ser visto "como uma parte da atividade da Administração, destinada a manter a ordem, a tranqüilidade, a salubridade e o uso livre das coisas públicas. Aos poucos deixou-se de usar o vocábulo polícia isoladamente para designar essa parte da atividade da Administração". ${ }^{13}$ Por isso, com o Estado Liberal, intervencionista na sua forma, sua atuação limitou-se à segurança, com extensão à ordem econômica e social, sofrendo a pessoa um limite na sua liberdade, beneficiando o interesse público. ${ }^{14}$

Um segundo período, também dentro do Estado de Direito, era o Estado Social, ou do Bem-Estar, havendo uma ampliação no vocábulo, adquirindo o encargo de desenvolver e aplicar princípios constitucionais que consagrem direitos tanto econômicos como sociais, cujo Estado deveria buscar a igualdade, passando a interferir também na esfera privada, sendo editadas muitas normas, passando com isso a ser um "Estado Legal". O poder de polícia foi ampliado, "é atividade do Estado consistente em limitar o exercício dos direitos individuais em benefício do interesse público, qualquer que seja a sua natureza". ${ }^{15}$

A busca por uma igualdade social foi trazida para o Direito Público, em especial para o Direito Administrativo, pois fazia-se necessária a intervenção do Estado para efetivar o equilíbrio entre direitos individuais. ${ }^{16}$

11 DI PIETRO. M. S. Z. Discricionariedade administrativa na Constituição de 1988. São Paulo: Atlas, 1991, p. 17

12 TÁCITO, C. Poder de polícia. In: Boletim de Direito Municipal-BDM, jun. 95, Pernambuco, 1994, p. 269.

13 MEDAUAR. Poder de polícia..., p. 90-91; e MEDAUAR. Direito administrativo..., p. 389.

14 DI PIETRO. Direito administrativo..., p. 93-94.

15 DI PIETRO. Discricionariedade..., p. 25.

16 TÁCITO, Poder de polícia..., p. 270. "Se transpõe, assim, de um puro aspecto negativo (que marca a primeira fase de sua concepção) para um teor positivo, em que o Estado se oferece como árbitro entre interesses sociais dominantes, sem prejuízo da intervenção estatal direta para a prestação de serviços essenciais à comunidade". 
E um terceiro período, ainda dentro do Estado de Direito, é o Estado Democrático, com a participação obrigatória da população, em nível constitucional nas decisões e no controle da Administração pública, com novas concepções, vinculando a lei aos ideais de justiça social. O poder de polícia estendeu-se a diversas áreas, onde, inclusive, antes não se fazia necessária a exemplo da proteção ambiental e ao consumidor.

A evolução do poder de polícia acompanhou o desenvolvimento das cidades e a "multiplicação das atividades humanas, a expansão dos direitos individuais e as exigências do interesse social". ${ }^{17}$

Possuímos atualmente no Brasil um Estado Democrático de Direito, com um amplo e forte direito administrativo e, assim, temos um regime jurídico-administrativo ao qual é submetida a Administração pública, sendo relevantes dois aspectos opostos: as prerrogativas, que são a autoridade da Administração pública, "concedidas à Administração para oferecer-lhe meios para assegurar o exercício de suas atividades"; e as sujeições, que são a liberdade individual, "como limites opostos à atuação administrativa em benefício dos direitos dos cidadãos". ${ }^{18}$

Assim, o tema relativo ao poder de polícia coloca em contraposição esses dois aspectos: o cidadão, de um lado, que deseja exercer seus direitos, e a Administração, do outro lado, que possui a incumbência de tornar efetivo o exercício dos direitos, usando para isso esse poder que está fundado no princípio da predominância do interesse público sobre o particular.

\subsection{Noções apresentadas pela doutrina e pela legislação}

Necessário se torna trazer as noções e conceituações elaboradas e oferecidas ao longo dos tempos pelos doutrinadores e também pela legislação do poder de polícia, servindo de base para o desenvolvimento do tema.

Originariamente a noção de poder de polícia era concebida como realização de um dever geral, incumbindo ao súdito a não-perturbação da coisa pública. Eram as ordens dadas aos indivíduos que, segundo MAYER, nunca teriam outro fim "senão o de combater aquela perturbação". ${ }^{19}$

Paralelamente a essa abordagem, assinala DI PIETRO um conceito clássico, ligado à concepção liberal do século XVIII, cujo poder de polícia "compreendia a atividade estatal que limitava o exercício dos direitos individuais em benefício da segurança". E um conceito moderno, adotado na sistemática brasileira, que "é a atividade

17 MEIRELLES, H. L. Direito municipal brasileiro. 10. ed. São Paulo: Malheiros, 1998, p. 351.

18 DI PIETRO. Direito administrativo..., p. 92.

19 GRAU, E. R. Poder de polícia: Função administrativa e princípio da legalidade: O chamado "direito alternativo". In: Revista Trimestral de Direito Público n. 1, p. 93-94. "A previsão do seu exercício aparece, na França, inscrita em norma de 22.12.1789/8.1.1790, na afirmação de que competia aos administradores dos Departamentos a 'manutenção da salubridade, da segurança e da tranqüilidade públicas"”. 
do Estado consistente em limitar o exercício dos direitos individuais em benefício do interesse público". ${ }^{20}$

Hoje, porém, o poder de polícia é tido como "faculdade de que dispõe a Administração Pública para condicionar e restringir o uso e gozo de bens, atividades e direitos individuais, em benefício da coletividade ou do próprio Estado", como bem aborda HELY LOPES MEIRELLES, e acrescenta: "é o mecanismo de frenagem de que dispõe a Administração Pública para conter os abusos do direito individual. Por esse mecanismo, que faz parte de toda a Administração. O Estado detém a atividade dos particulares que se revelar contrária, nociva ou inconveniente ao bem-estar social, ao desenvolvimento e à segurança nacional". ${ }^{21}$

No mesmo sentido TOSCHIO MUKAI traz o poder de polícia como "uma faculdade, inerente à Administração Pública, que esta detém, para disciplinar e restringir as atividades, o uso e gozo de bens e de direitos, bem assim as liberdades dos administrados, em benefício da coletividade". ${ }^{22}$

Corroborando com esse pensamento, ODETE MEDAUAR tem o poder de polícia como "atividade da Administração Pública que impõe limites a direitos e liberdades". Tema este que insere-se "na encruzilhada autoridade-liberdade, Estadoindivíduo, que permeia o direito administrativo e o direito público, revelando-se pois muito sensível à índole do Estado e às características históricas, políticas e econômicas dos países". Assim, essa noção "permite expressar a realidade de um poder da Administração de limitar, de modo direto, liberdades fundamentais em prol do bem comum". ${ }^{23}$

É o que expressa também CAIO TÁCITO, para quem o poder de polícia "é fundamentalmente uma limitação administrativa a um direito ou liberdade, em benefício de um interesse qualificado em lei, e supõe uma norma expressa de competência, ou seja, a ninguém é lícita a autopromoção do poder de polícia". ${ }^{24}$

Ou ainda, como expõe ODÍLIA OLIVEIRA, como "conjunto de atribuições da Administração Pública, consistentes em atos normativos e atos individuais executórios, de fiscalização e controle da atividade privada, não só mediante a prevenção, mas também por via da repressão de atos violadores da ordem jurídica, que tenham repercussão social". ${ }^{25}$

20 DI PIETRO. Direito administrativo..., p. 94-95.

21 MEIRELLES, H. L. Direito administrativo brasileiro. 25. ed. São Paulo: Malheiros, 2000, p. 122. Nesse sentido, também MEIRELLES. Direito municipal brasileiro..., p. 351.

22 MUKAI, T. Direito administrativo sistematizado. São Paulo: Saraiva, 1999, p. 89.

23 MEDAUAR. Poder de polícia..., p. 89 e 94; e MEDAUAR. Direito administrativo..., p. 387-399.

24 TÁCITO. Poder de polícia..., p. 272.

25 OLIVEIRA, O. F. da L. Implicações da distinção entre poder de polícia e serviço público. In: Revista de Direito Público, n. 74, p. 208-209. 
Por oportuno, há que se destacar também o poder de polícia num sentido amplo e num sentido estrito como oferecido por BANDEIRA DE MELLO, como atividade estatal condicionadora da liberdade e propriedade, visando a interesses coletivos.

Em seu sentido amplo "abrange tanto atos do Legislativo quanto do Executivo. Refere-se, pois, ao complexo de medidas do Estado que delineia a esfera juridicamente tutelada da liberdade e da propriedade dos cidadãos". Em seu sentido estrito, "relacionando-se unicamente com as intervenções, quer gerais e abstratas, como os regulamentos, quer concretas e específicas (...) do Poder Executivo destinadas a alcançar o mesmo fim de prevenir e obstar ao desenvolvimento de atividades particulares contrastantes com os interesses sociais". ${ }^{26}$

Seguindo a mesma linha de raciocínio, EROS GRAU aduz que o sentido amplo é usado "para significar tanto medidas estatais, do Legislativo e do Executivo, que afetem a propriedade e a liberdade", e o sentido estrito, "quanto a atos da Administração, destinados a prevenir e impedir a prática de atividades que confrontem o chamado interesse social". ${ }^{27}$

Em sentido similar, destaca JUAN FRANCISCO LINARES três acepções da expressão "poder de polícia" no direito Argentino: amplíssima, ampla e estrita. Vejamos: a) A primeira é amplíssima - "Parte del poder del Estado que se ejercita a través de normas del derecho público para reglar la libertad jurídica individual”; b) A segunda é ampla - "La parte del poder mencionado en a que se refiere sólo a materias de orden, seguridad, moralidad, salubridad, estética y bienstar público, ejercida por los tresórganos del Estado sobre la libertad jurídica individual. Queda fuera del concepto la legilación de derecho común, impositiva, sobre educación, defensa, relaciones internacionales y otras"; e c) A terceira é estrita-A polícia "ejercida sobre la liberdad jurídica individual sólo como 'funcion administrativa' de la Administracion y de los otros dos poderes, en aplicación de leyes de policía en sentido amplio, es decir, las conciernentes a seguridad, saliubridad, moralidad, estética y bienestar general esta policía se hace efectiva mediante actos y hechos administrativos en sentido material y objetivo". ${ }^{28}$

Não importa, entretanto, qual abordagem se adote, se ampla, estrita, ou outra. O fato é que o poder de polícia é a atividade da Administração Pública ou o conjunto de atividades dadas ao Estado, com poder de impor limitação administrativa, com intuito de disciplinar e restringir direitos e liberdades individuais, visando unicamente ao interesse público.

Noutra seara, CRETELLA JR. traz que o poder de polícia, por informar o ordenamento jurídico, deve satisfazer um tríplice objetivo: "de assegurar a tranqüilidade, a segurança, a salubridade públicas", visando a tal finalidade, vez que é a faculdade discricionária que limita liberdades, objetivando um interesse comunitário. ${ }^{29}$

26 MELLO, C. A. B. de. Curso de direito administrativo. 12. ed. rev. atual. e ampl. São Paulo: Malheiros, 2000, p. 666. Vide também DI PIETRO. Direito administrativo..., p. 95.

27 GRAU, op. cit., p. 94

28 LINARES, J. F. Derecho administrativo. Buenos Aires: Astrea, 1986, p. 421.

29 CRETElla JUNIOR, J. Direito administrativo do Brasil. Poder de polícia. São Paulo: Revista dos Tribunais, v. IV, 1961, p. 54. 
Todavia, no Brasil, adverte BANDEIRA DE MELLO, como só há regulamentos executivos, para execução das leis, fugindo à alçada regulamentar qualquer inovação na ordem jurídica, "não interessa indagar se se trata de segurança, ordem ou salubridade públicas, ou qualquer outro setor, uma vez que se encontram niveladas todas as intervenções da Administração", ou, como informa CIRNE LIMA, intervenção reguladora da administração pública, ${ }^{30}$ pois nosso sistema é diferente do modelo francês,${ }^{31}$ donde provém esse tríplice objetivo, pois diferenciam a polícia geral da especial. ${ }^{32}$

Então não há que se inferir se há o tríplice objetivo: segurança, ordem ou salubridade públicas.

Nesse contexto, enfatizou nossa doutrina conceitos que visam a definir o que se entende por poder de polícia, e assim também procedeu nossa legislação, no art. 78 do Código Tributário Nacional, referente à cobrança de taxa:

"Considera-se poder de polícia da atividade da administração pública que, limitando ou disciplinando direito, interesse ou liberdade, regula a prática de ato ou abstenção de fato, em razão de interesse público concernente à segurança, à higiene, à ordem, aos costumes, à disciplina da produção e do mercado, ao exercício de atividades econômicas dependentes de concessão ou autorização do Poder Público, à tranqüilidade pública ou ao respeito à propriedade e aos direitos individuais ou coletivos."

Também nossa Constituição Federal de 1988 assim o fez, abordando o poder de polícia em muitos artigos e incisos, a exemplo do art. $5^{\circ}$, VI e VIII, XIII, XVI, XXIII e XXIV, art. 145, II, art. 170 e art. 172, entre outros.

Note-se: temos noções das mais variadas, elaboradas ao longo dos anos, tanto na doutrina como na legislação, mas todas elas trazem o poder de polícia como um limite ao exercício de um direito individual, beneficiando a coletividade, prevenindo ou reprimindo atos violadores.

\subsection{A expressão poder de polícia}

A expressão poder de polícia teve origem jurisprudencial, pois nasceu no direito norte-americano, sendo criado por eminentes juízes.

30 LIMA, op. cit., p. 108-110. "No velho direito, estendia-se a polícia à ordem jurídica (...). No presente, adscreve-se, ao inverso, a polícia ao mundo dos fatos".

31 CRETELLA, op. cit., p. 49, "na França (seguida de perto pela Itália, a defesa da ordem pública, da segurança, da salubridade, é o objetivo máximo do poder de polícia, na jurisprudência e doutrina norte-americanas transcende aquele poder às formas constritivas de direitos individuais promanadas da Administração para estender-se, principalmente, até o exercício da função legislativa".

32 MELLO. Curso de direito..., p. 675-677. Tem os franceses a polícia geral como "atividade de limitação ao exercício da liberdade e da propriedade dos indivíduos quando preordenada a assegurar a tranqüilidade, a segurança e a salubridade públicas" e, a polícia especial, como "aquela concernente aos outros diversos ramos de atuação da polícia administrativa". 
Nesse sentido, leciona CRETELLA JR. que, em 1827, no caso Brown versus Maryland, "o juiz MARSHALL, presidente da Corte Suprema dos Estados Unidos, trata do poder de polícia, se bem que a expressão integral, esteriotipada-police power - ainda não lhe tivesse ocorrido de modo nítido, tanto assim que, em seu voto, nada menos que 19 vocábulos se interpõem entre os termos constitutivos da denominação". ${ }^{33}$

A expressão poder de polícia, vigente na sistemática brasileira, é a tradução pura e simples da expressão norte-americana police power. Todavia, como leciona ODÍLIA OLIVEIRA, nos Estados Unidos, esse police power "é função legislativa, de fazer leis limitadoras das atividades individuais, em benefício do bem-estar coletivo" e, entre nós, que seguimos o modelo europeu, o poder de polícia "é função exclusivamente administrativa, infralegal, portanto, e que se desdobra em atos normativos de caráter regulamentar e atos individuais de efeitos concretos, expedidos para a execução das leis que limitam a atividade dos administrados". ${ }^{34}$

Ressalte-se: mesmo que tenhamos adotado uma tradução do direito americano, e muito embora sigamos orientações do direito europeu, temos que ter presente que o poder de polícia deve ser utilizado na sistemática brasileira como uma faculdade que possui a Administração Pública como restrição ou condição de bens, direitos e atividades, em detrimento da coletividade.

Adverte, por outra via, BANDEIRA DE MELLO que a expressão poder de polícia traz consigo "a evocação de uma época pretérita, a do 'Estado de Polícia', que precedeu ao Estado de Direito". Trazendo uma suposição de prerrogativas dadas ao Príncipe, que são hoje inadvertidamente dadas ao Executivo. Assim, "raciocina-se como se existisse uma 'natural' titularidade de poderes em prol da Administração e como se dela emanasse intrinsicamente, fruto de um abstrato "poder de polícia". ${ }^{35}$

Atualmente, na maioria dos países europeus, com exceção da França, o tema é abordado com o título de limitações administrativas à liberdade e à propriedade, em vez de poder de polícia. Entretanto, o poder de polícia é e será usado, na legislação brasileira, quando referido "tanto às leis condicionadoras da liberdade e da propriedade quanto aos atos administrativos pelos quais se procede a suas concreções". ${ }^{36}$

O engano cometido por parte da doutrina, com a expressão poder de polícia, causando equívocos, provém, segundo EROS GRAU, de que não há um "poder" de polícia, mas uma função - função administrativa, e por não ser nem prerrogativa nem faculdade, tem-se um dever-poder vinculando sua vontade, e por isso referir como atividade sub-legal. ${ }^{37}$

33 CRETELLA JUNIOR, op. cit., p. 45-46.

34 OLIVEIRA, O., op. cit., p. 208.

35 MELLO. Curso de direito..., p. 665.

36 MELLO. Curso de direito..., p. 665.

37 GRAU, op. cit., p. 94-95. "O Poder é um só, observa GORDILLO e a chamada divisão de três 'poderes' consiste, por um lado, em uma divisão de funções, e por outro em uma separação de órgãos. Não há, pois, um Poder de polícia. De outra parte, a alusão a um poder de polícia veicula a idéia de prerrogativa titulada pela Administração". 
AGUSTÍN GORDILLO, mencionado por LUCIA VALLE, repele a idéia de poder de polícia, "por entendê-la defasada no tempo, criticando a conotação dada ao mesmo, como sendo uma atividade de 'não fazer' em lugar de 'fazer'". Assim, as restrições à liberdade e propriedade estão estabelecidas em lei, cumprindo à Administração um agir conforme a lei. E, por estar sempre ligada à idéia de limitações ou restrições, há que se observar, fundamentalmente, que tudo irá depender do prisma do observador. ${ }^{38}$

Gize-se: no Brasil, por força da conveniência, o termo poder de polícia vige entre nós, e não há porque substituí-lo por outro termo; necessária, sim, uma maior compreensão de seu significado, abrangência, limitações e utilização.

Nesse contexto, o exercício do poder de polícia se dá sempre que verificado um agir anti-social de um particular contra a sociedade. E, a controvérsia no seu conceito, é justamente a verificação do aspecto negativo, quando previne um dano, e no aspecto positivo, quando caracteriza ação ostensiva e legítima da administração, além de outra questão conceitual, do poder, que não é "da" polícia mas "de" polícia, "não é privativo, portanto, da polícia o exercício do poder de polícia. Ele é amplo e difuso para exercício de toda a administração pública". ${ }^{39}$

Notou bem: o poder não é "da" polícia, mas "de" polícia, aplicável pela Administração.

\subsection{Polícia administrativa e polícia judiciária}

Por estarmos tratando da Administração Pública, tem a polícia administrativa uma maior importância no desenvolvimento deste trabalho. Cumpre referir, porém, pelo menos numa rápida abordagem, também a polícia judiciária, apresentando alguns aspectos diferenciadores.

A expressão polícia administrativa surgiu primeiro na França, como bem informa ODETE MEDAUAR, "quando o Código do 3 Brumário do ano IV (1795) mencionou a divisão da polícia em polícia administrativa e polícia judiciária". Foi dada à primeira a ordem pública, da segurança, tranqüilidade e salubridade, e, à segunda, a apuração material dos delitos. ${ }^{40}$

BANDEIRA DE MELLO tem a polícia administrativa como "a atividade da Administração Pública, expressa em atos normativos ou concretos, de condicionar, com fundamento em sua supremacia geral e na forma da lei, a liberdade e a propriedade dos indivíduos", e acrescenta, ora frente a uma ação "fiscalizadora, ora preventiva, ora repressiva, impondo coercitivamente aos particulares um dever de abstenção (non facere)

38 FIGUEIREDO, L. V. Curso de direito administrativo. 4. ed. rev. ampl. e atual. São Paulo: Malheiros, 2000, p. 283-285.

39 LUZ, E. M. Direito administrativo contemporâneo. Curitiba: Juruá, 2000, p. 63.

40 MEDAUAR. Poder de polícia ..., p. 90-91; e MEDAUAR. Direito administrativo..., p. 387-389. 
a fim de conformar-lhes os comportamentos aos interesses sociais consagrados no sistema normativo". ${ }^{41}$

Por isso, não se pode confundir o poder de polícia administrativamente falando, visto que "significa a emissão de vários instrumentos formais para regular o comportamento ou interesse coletivo", com o poder de polícia judiciariamente considerado, encontrando-se, neste, "medidas legítimas para serem adotadas coercitivamente contra aquele ou aqueles responsáveis pela turbação do convívio social". ${ }^{42}$

É dizer que a polícia administrativa condiciona-se a "impedir ou paralisar atividades anti-sociais", enquanto a polícia judiciária "se preordena à responsabilização dos violadores da ordem jurídica". ${ }^{43}$

Assim, temos o caráter preventivo da polícia administrativa, objetivando impedir ações anti-sociais e o caráter repressivo da polícia judiciária, objetivando punir infratores da lei penal.

DI PIETRO, trazendo importante lição de ÁLVARO LAZZARINI, coloca que a linha "de diferenciação está na ocorrência ou não de ilícito penal. Com efeito, quando atua na área do ilícito puramente administrativo (preventiva ou repressivamente), a polícia é administrativa. Quando o ilícito penal é praticado, é a polícia judiciária que age. A primeira se rege pelo direito administrativo, incidindo sobre bens, direitos ou atividades; a segunda, pelo direito processual penal, incidindo sobre pessoas". ${ }^{44}$

Portanto, temos que a polícia administrativa "se reparte entre diversos órgãos da Administração, incluindo, além da própria polícia militar, os vários órgãos de fiscalização aos quais a lei atribua esse mister, como os que atuam nas áreas da saúde, educação, trabalho, previdência e assistência social", e a polícia judiciária que "é privativa de corporações especializadas (polícia civil e militar)" ${ }^{45}$

Bem demonstra isso FERNANDO ANDRADE DE OLIVEIRA: que os órgãos e as entidades que compõem a polícia administrativa, exercendo uma especial manifestação do poder estatal, correspondente ao poder de polícia, atuam na tutela do interesse público, devendo o Estado "fomentar as iniciativas dos particulares, econômica e socialmente úteis e, concomitantemente, coibir as ações e omissões nocivas, segundo o ordenamento jurídico". Por outro lado, a polícia judiciária atua num setor apenas, "da apuração da materialidade e autoria dos delitos; carece de poder para impor sanções

41 MELlO, Curso de direito..., p. 675 e 684. Pode-se dizer que a polícia administrativa "propõe-se a salvaguardar os seguintes valores: a) de segurança pública; b) de ordem pública; c) de tranqüilidade pública; d) de higiene e saúde pública; e) estéticos e artísticos; f) históricos e paisagísticos; g) riquezas naturais; h) de moralidade pública; i) economia popular". Vide também MEDAUAR. Direito administrativo..., p. 394-395.

42 LUZ, op. cit., p. 62-63.

43 MELLO. Curso de direito..., p. 673.

44 DI PIETRO. Direito administrativo..., p. 96.

45 Ibid., p. 96. 
embora possa praticar atos de coação cautelar, de prisão de indiciados como delinqüentes e de apreensão de bens, como meio de prova dos delitos; é exercida conforme a legislação processual penal, que não comporta regulamentação". ${ }^{46}$

No mesmo sentido, MEIRELLES distingue, ainda, além da polícia administrativa e judiciária, também a polícia de manutenção da ordem pública. A administrativa "incide sobre os bens, direitos e atividades", sendo inerente e difusa, da Administração Pública em geral; já a judiciária e a da ordem pública "atuam sobre pessoas, individualmente ou indiscriminadamente", sendo privativas de certos órgãos como as polícias civis, ou corporações como as polícias militares. ${ }^{47}$

Destaque-se: a polícia administrativa tem importância fundamental na Administração Pública, vez que, regida pelo direito administrativo, vai inferir sempre sobre algum comportamento administrativo relacionado a bens, direitos ou atividades, destacando-se entre os poderes administrativos justamente porque exerce tais atividades, que afetam a sociedade.

\section{DISCRICIONARIEDADE}

\subsection{Origem e evolução}

A discricionariedade, num aspecto geral, vem de discrição, do latim discretio, de discernere, significando discernir, ou distinguir e exprime, portanto, o discricionário, pondo-se à discrição de outrem, deixando a seu livre arbítrio, para deliberação ou resolução, segundo as necessidades dos casos concretos, do momento ou ainda conforme as circunstâncias. Já no âmbito do Direito, significa o que fica "ao critério, ao juízo ou ao arbítrio de outrem", cuja faculdade ou a autorização, dada à autoridade pública, para determinadas circunstâncias, delibere ou resolva livremente. Tido como um amplo poder, pelo qual a autoridade determine quais medidas ou meios são próprios para a resolução dos casos. ${ }^{48}$

Antes mesmo de figurar no direito administrativo, a discricionariedade indicava uma espécie de atributo dado ao soberano, expressando tanto sua aptidão, como a de seus agentes, para o bom e fiel cumprimento e desempenho das funções. ${ }^{49}$

Após este período, da Era absolutista, temos o Estado de Direito, no qual a discricionariedade assumiu um aspecto mais jurídico, pois passou a ser limitada pela lei - não uma liberdade de atuação, tendo por limite a lei, mas uma liberdade de atuação tendo por limite o próprio Direito -, mantendo esse caráter até hoje, com algumas modificações.

46 OLIVEIRA, F. A. de. A administração pública na Constituição de 1988 ( $1^{\mathrm{a}}$ parte). In: Revista de Direito Administrativo. Rio de Janeiro: Renovar, 184 abr./jun. 1991, p. 14.

47 MEIRELLES, Direito administrativo brasileiro..., p. 122. Nesse sentido, também MEIRELLES. Direito municipal brasileiro..., p. 351.

48 DE PLÁCIDO E SILVA, op. cit., p. 614.

49 MEDAUAR. Direito administrativo..., p. 127. 
É praticamente impossível cogitar-se de um poder discricionário que esteja "fora do Direito, subtraído a toda disciplina legal"; significa, sim, "uma condição de liberdade, mas não liberdade ilimitada; trata-se de liberdade onerosa, sujeita a vínculo de natureza peculiar". ${ }^{50}$

Dentro desse Estado de Direito, temos um primeiro período - o Estado Liberal -, cuja discricionariedade era vista como uma atividade administrativa, como simples execução legal, mas, por outro lado, havia outra atividade, de livre apreciação, "na qual a Administração Pública atuava isenta de vinculação legal e, portanto, de controle judicial. Era a forma como se concebia a discricionariedade nesse período". Não era tida como sendo um poder jurídico, mas puramente como um poder político, reconheciase à Administração esta ampla discricionariedade, porém no espaço deixado pela lei, "significando que ela pode fazer tudo o que a lei não proíbe". ${ }^{51}$

Um segundo período, também dentro do Estado de Direito, era o Estado Social, não havendo mais aquela discricionariedade do período liberal, mas uma vinculação à lei, passando a abranger a totalidade da atividade administrativa, cuja Administração "só pode fazer o que a lei permite". ${ }^{52}$ Não mais o que a lei não proíbe.

E um terceiro período, ainda dentro do Estado de Direito, é o Estado Democrático, deixando a discricionariedade de ser aquele poder político, transformandose definitivamente num poder jurídico, ${ }^{53}$ abrangendo o aspecto democrático de participação do povo e o aspecto de direito, relacionado à justiça material.

Contudo, podemos referir que, desde sua origem e evolução no decorrer dos tempos, a discricionariedade foi - e é - fundamental no direito administrativo, e isso pode ser visto a partir das noções apresentadas pela doutrina e jurisprudência pátria e estrangeira, visando a perfectibilizar o fim último, de interesse público, dentro da legalidade e dentro de um aspecto mais amplo de justiça.

\subsection{Noções apresentadas pela doutrina}

Quem melhor traz, em nosso entender, uma noção do que pode ser entendido por discricionariedade é CELSO ANTÔNIO BANDEIRA DE MELLO, como liberdade dentro da lei, ínsita em limitações normativas legais, definindo-a como "margem de liberdade conferida pela lei ao administrador a fim de que este cumpra o dever de integrar com sua vontade ou juízo a norma jurídica, diante do caso concreto, segundo critérios subjetivos próprios, a fim de dar satisfação aos objetivos consagrados no sistema legal". ${ }^{4-55}$

50 MEDAUAR. Direito administrativo..., p. 129.

51 DI PIETRO. Discricionariedade..., p. 19 e 27.

52 Ibid., p. 27.

53 Ibidem., p. 19 e 27

54 MELLO, Curso de direito..., 12. ed., p. 745.

55 MELLO, C. A. B. de. Discricionariedade e controle jurisdicional. 2. ed. São Paulo: Malheiros, 1993, p. 48. Nesta obra, refere um conceito de discricionariedade: "é a margem de liberdade que remaneça 
Segundo ERNST FÖRSTHOFF, citado por JUAREZ FREITAS, o poder discricionário significa "que a ordem jurídica tem para conforme ao Direito tudo o que for julgado oportuno pela Administração", exercido conforme o interesse geral. ${ }^{56}$

A discricionariedade é, portanto, aquela margem de liberdade dada ao administrador para que possa, baseado em critérios de razoabilidade, eleger um entre mais comportamentos, verificando cada caso, com a finalidade legal de cumprir seu dever, de optar, adotando a solução que mais lhe pareça ser a adequada, quando a própria lei ou mesmo essa liberdade de escolha não lhe dêem condições de objetivamente obter uma única solução para a contenda. ${ }^{57}$

A Administração Pública, que aprecia ou avalia a aplicação dos limites legais da liberdade e propriedade, em certas circunstâncias, age discricionariamente quando a lei deixa ao administrado essa faculdade, ou esse dever, ou, como refere VLADIMIR FRANÇA, no âmbito do regime jurídico-administrativo, um dever-poder discricionário, ${ }^{58}$ verificando a melhor forma de aplicar e satisfazer este mandamus.

Neste particular, a discricionariedade administrativa também é tida como "a faculdade que a lei confere à Administração para apreciar o caso concreto, segundo critérios de oportunidade e conveniência, e escolher uma dentre duas ou mais soluções, todas válidas perante o direito". ${ }^{59}$ Também, neste sentido, a discricionariedade em essência é "a faculdade conferida à autoridade administrativa de, ante certa circunstância, escolher uma entre várias soluções possíveis". ${ }^{60}$

Não obstante, MEIRELLES aponta a discricionariedade como "liberdade de ação administrativa, dentro dos limites permitidos em lei", fazendo uma diferenciação entre o ato e o poder discricionário. Os atos discricionários são os que a administração "pode praticar com liberdade de escolha de seu conteúdo, de seu destinatário, de sua conveniência, de sua oportunidade e do modo de sua realização. A rigor, a discricionariedade não se manifesta no ato em si, mas sim no poder de a Administração praticá-lo pela maneira e nas condições que repute mais convenientes ao interesse público". ${ }^{61}$

ao administrador para eleger, segundo critérios consistentes de razoabilidade, um, dentre pelo menos dois comportamentos cabíveis, perante cada caso concreto, a fim de cumprir o dever de adotar a solução mais adequada à satisfação da finalidade legal, quando, por força da fluidez das expressões da lei ou da liberdade conferida no mandamento, dela não se possa extrair objetivamente, uma solução unívoca para situação vertente".

56 FREITAS, J. Estudos de direito administrativo. 2. ed. rev. e atual. São Paulo: Malheiros, 1997, p. 137.

57 MELLO. Curso de direito..., 12. ed., p. 761.

58 FRANÇA, V. da R. Vinculação e discricionariedade nos atos administrativos. In: Revista de Direito Administrativo, Rio de Janeiro: FVG-Renovar, n. 222, p. 98, out./dez. 2000.

59 DI PIETRO. Discricionariedade..., p. 41.

60 MEDAUAR. Direito administrativo..., p. 126-128. Diferentes expressões são usadas hoje para designar a discricionariedade como: poder discricionário, que "seria a atribuição legal de decidir com possibilidade de escolha", atividade discricionária "refere-se ao exercício de funções com utilização do poder discricionário" e discricionariedade, que seria "a própria possibilidade de escolha". Todavia, todas são usadas como sinônimas, facilitando a compreensão.

61 MEIRELLES. Curso de direito administrativo..., p. 103 e 150-151. Nesse sentido, também MEIRELLES. Direito municipal brasileiro..., p. 356. 
As noções trazidas no direito pátrio guardam identidade conceitual com as noções oferecidas no direito comparado, a exemplo do ordenamento português, espanhol e argentino. Veja-se:

No direito português, segundo Queiró, o poder discricionário é concebido "como uma certa margem de liberdade, concedida deliberadamente pelo legislador à Administração, a fim de que esta escolha o comportamento mais adequado para a realização de um determinado fim público", ou seja, é uma faculdade de escolha dentre diferentes significados que estão dentro de um conceito normativo, referindo-se ao agir administrativo, mas esta escolha é feita necessariamente observados os limites legais. Consiste ainda numa "outorga de liberdade, feita pelo legislador à Administração numa intencional concessão do poder de escolha, ante o qual se legitimam, como igualmente legais, igualmente correctas de lege lata, todas as decisões que couberem dentro da série, mais ou menos ampla, daquelas entre as quais a liberdade de acção administrativa foi pelo legislador confirmada". Trata a discricionariedade, portanto, "de comitir à Administração o encargo de eleger a medida ou procedimento mais idôneo à prossecução de uma finalidade pública cuja realização é reputada necessária pelo legislador", isso dentro de certos limites, para escolher a medida que seja mais eficiente, visando sempre realizar o interesse público. ${ }^{62}$

Também ANDRÉ GONÇALVES PEREIRA traz ainda que a discricionariedade no direito português é tida como "a faculdade de escolha, concedida pelo legislador à administração, dentre uma série limitada de bens jurídicos adequados à satisfação de uma certa necessidade pública". ${ }^{63}$

Por outro lado, traz SALAVERRÍA, no direito espanhol, que a grande questão é identificar a discricionariedade como algo a posteriori e não a priori, pois "la $<<$ discrecionalidad $>>$ no es un prius ante un espacio que se oferta a la Administración para que ésta actúe dentro de aquél com holgura, sino un posterius". Assim, há esta margem de discricionariedade quando aparecem várias soluções razoáveis, sendo necessário eleger-se dentre elas uma apenas. E destaca que margem discricional "no es algo dado a priori sino algo ganado (en la medida en que los contendientes son capaces de defender soluciones alternativas razonables). Por ello. El ejercicio de la potestad discrecional pressupone dos elementos: una opcion (entre varias soluciones realmente posibles) razonable (en un marco socio-cultural determinado)". ${ }^{64}$

62 QUEIRÓ, A. R. Os limites do poder discricionário das autoridades administrativas. In: Estudos de Direito Administrativo I. Atlântida: Coimbra, 1967, p. 8-10.

63 PEREIRA, A. G. Erro e ilegalidade no acto administrativo. Coleção Jurídica Portuguesa, n. 22, São Paulo: Ática, [19-], p. 227.

64 SALAVERRÍA, J. I. Discricionalidad técnica, motivación y control jurisdiccional. Madrid: Civitas, 1998, p. 35-36 e 45. Aponta ainda como relevantes três noções discricionais, classificando-a em estrutural, textual e estratégica. Estructural "cuando, dado un supuesto de hecho, la norma no prescribe una consecuencia jurídica y confía a la Administración la tarea de fijar la regla de su propia actuación". Textual "cuando en la disposición normativa comparecen expressiones que remiten directamente al caráter discrecional de la potestad en custión o, com mayor frecuencia, usan fórmulas como $<<$ poderá $>>,<<$ tiene facultad $>>$ e outras del mismo aire". Estratégico "cuando las normas imponem fines y objetivos pero no predeterminan los medios para arribar al fin u objetivo estabelecido". 
Contrariamente às posições apresentadas, MIGUEL SÁNCHEZ MÓRON diz ser equivocada a definição dada de discricionariedade no direto espanhol "como una capacidad incondicionada de imposición $>>$, una potestad $<<$ libre y extenta de qualquier posible fiscalización o correción desde fuera, de dar cuenta de sí misma, de justificar-se en una palabra >>, como a trazida por FERNANDEZ RODRIGUEZ, porque não corresponde mais com as circunstâncias do presente em um regime Democrático de Direito como o atual, pois toda atividade administrativa está submetida por um lado "a la crítica de una opinión pública libre de una sociedad que puede mobilizarse para alcanzar sus objetivos", e, por outro, "a la responsabilidad política que esa misma sociedad hace efectiva periódicamente y a la crítica igualmente política que formulan los grupos de oposición en los foros constitucional o legalmente previstos". ${ }^{65}$

Por fim, há que ser observado o aspecto legal, pois tem-se advertido que a discricionariedade não se encontra à margem da lei, mas sim dentro da lei, não sendo uma imprevisão legislativa, mas uma manifestação expressa da vontade do legislador, é dizer dentro dos limites legais. ${ }^{66} \mathrm{E}$ isso fica ainda mais evidente com a abordagem trazida no próximo item, no que se refere à diferenciação entre discricionariedade $\mathrm{e}$ vinculação.

\subsection{Discricionariedade e vinculação}

Como já fora identificado, atos discricionários são os que a Administração pratica com certa margem de liberdade, podendo avaliar ou decidir conforme um critério que seja mais conveniente e oportuno, mesmo que adstrito à lei. Há que se identificar também agora os atos vinculados como aqueles que tem a Administração, prévia e objetivamente tipificados na lei, como um único comportamento possível, frente a uma situação também legalmente prevista, sem interferência subjetiva. ${ }^{67}$

Se os atos discricionários são os praticados pela Administração, com liberdade de escolha, tanto de conteúdo, como destinatário, conveniência, oportunidade e modo de realização, os atos vinculados também tidos como regrados são aqueles em que a lei

65 MÓRON, M. S. Discrecionalidad administrativa y control judicial. Madrid: Tecnos, 1994, p. 154.

66 TAWIL, G. S. Administración y Justicia. Alcance del control judicial de la actividad administatriva. Buenos Aires: Depalma, 1993, p. 39-40. Explica: "No resulta possible aceptar en la actualidad, por ejemplo, que la discricionariedad administrativa pueda resulatar producto de um vacío legal o laguna normativa (.. La superación de esta identificación entre discrecionariedad y falta de norma determinante o laguna legal, há permitido compreender en forma mayoritaria que la estimación subjetiva o discrecional por parte de los entes administrativos sólo puede resultar consecuencia de haber sido llamada expressamente por la ley al configurar una potestad y atribuirla a la Administración com ese caráter". Por outro lado "se há advertido así que la discrecionariedade no se encuentra al margen de la ley sino dentro de ella; es decir, que no se trata de una imprevisión legislativa, sino de una manifestación expressa de la voluntad del legislador".

67 MELLO. Curso de direito..., 12. ed., p. 750.

68 MEIRELLES. Curso de direito administrativo..., p. 149-150. 
estabelece tanto os requisitos como as condições de sua realização, sendo que nesta espécie a ação do administrador fica restrita aos pressupostos normativos. ${ }^{68}$

Segundo JUAREZ FREITAS, é aquele em que "o agente público, no âmbito da Administração direta ou indireta, não goza de qualquer liberdade, estando jungido a cumprir os comandos legais". ${ }^{69}$

Todavia, assim como o sistema jurídico atribui poderes ao administrador público, este não pode ultrapassar certos limites, sob pena de o ato ser ilegal. Há que se observar, no entanto, que o poder será vinculado se as regras atingirem os diferentes aspectos de certa atividade, justamente por não ter a lei deixado uma opção, pois estabelece um dever de agir de tal ou tal maneira, diferente do que ocorre quando as regras não atingem todos os aspectos dessa atuação administrativa, por ter a lei deixado uma margem de liberdade, para que se possa decidir frente ao caso concreto, optando por uma dentre várias soluções possíveis, quando será discricionário. ${ }^{70}$

$\mathrm{O}$ ato vinculado é analisado somente quanto ao aspecto da legalidade, refere-se à conformidade do ato com a própria lei, em oposição ao ato discricionário, que é analisado tanto sob o aspecto da legalidade quanto do mérito, referindo-se à oportunidade e conveniência frente ao interesse público, mérito este, que só existe nos atos discricionários. $^{71}$

No ordenamento jurídico, é conferido ao administrador um poder de decisão, que o leva a uma direção: "por isso, na doutrina se diz que há matérias de reserva legal absoluta, em que o vínculo da Administração ao bloco de juridicidade é máximo. Se houver uma só solução, como conseqüência da aplicação de uma norma, ocorre o exercício do poder vinculado". ${ }^{72}$

ANDRÉ GONÇALVES PEREIRA aborda a importância dos atos frente a uma possível ilegalidade, visto que o poder discricionário não está adstrito a pressupostos, "na medida em que a lei não diz ou pode não dizer quais são os factos em que o agente deve basear a sua ação. Mas todo o acto administrativo tem de ter uma causa, e assim a determinação dos pressupostos faz-se sempre: ou pela lei (poder vinculado) ou pelo agente (poder discricionário)". E enfatiza que, em ambos os casos, "a inexatidão dos pressupostos acarreta a ilegalidade do acto por falta de causa". ${ }^{73}$

69 FREITAS, op. cit., p. 132-133.

70 DI PIETRO. Direito administrativo..., p. 176; DI PIETRO. Discricionariedade ..., p. 40.

71 Ibid., p. 180

72 MEDAUAR. Direito administrativo..., p. 126.

73 PEREIRA. Op. cit., p. 243. E faz também interessante comparação da discricionariedade e a interpretação, p. 57: "Sem dúvida a tarefa primeira do agente é a de individualizar a directiva contida na lei - fazendo tal dever parte do seu dever de ofício. Nesta tarefa de interpretação da lei não há porém discricionariedade mas sim vinculação - a discricionariedade começa quando termina a interpretação, e se verifica que o legislador quis dar valor jurídico à vontade psicológica do agente - mas então não há aí a individualizar qualquer directiva, que na lei não existe". 
Note-se: discricionário quando há opção legal e vinculado, segundo a lei.

\subsection{Discricionariedade e arbitrariedade}

A discricionariedade não pode ser confundida com a arbitrariedade. Falamos em discricionariedade quando estamos diante de uma liberdade de agir, baseada em limites legais, e falamos em arbitrariedade quando estamos diante de uma ação, que esteja fora ou além da legalidade, caracterizando-se abuso ou desvio de poder.

Obedecendo o ato discricionário a critérios legais, é considerado legítimo e válido, diferentemente do ato arbitrário, que é sempre ilegítimo e inválido: é dizer, nulo. Assim, refere MEIRELLES a importante observação tangenciada por MAYER de que "la regla de Derecho no puede ser violada por disposición de polícia; ésta no puede autorizar lo que dicha regra prohibe ni prohibir lo que ella permite". ${ }^{74}$

Por isso, não há que se confundir discricionariedade e arbitrariedade, segundo BANDEIRA DE MELLO, vez que, se agir arbitrariamente, "o agente estará agredindo a ordem jurídica, pois terá se comportado fora do que lhe permite a lei. Seu ato, em conseqüência, é ilícito e por isso mesmo corrigível judicialmente". Por outro lado, se agir discricionariamente, "o agente estará, quando a lei lhe outorga tal faculdade (que é simultaneamente um dever), cumprindo a determinação normativa de ajuizar sobre o melhor meio de dar satisfação ao interesse público por força da indeterminação legal quanto ao comportamento adequado à satisfação do interesse público no caso concreto". ${ }^{75}$

Neste sentido, também refere CAIO TÁCITO que o "arbítrio desconhece e desafia o direito; a discreção, ao contrário, se exerce e move, dentro do direito". ${ }^{76}$

Também não se confundem esses dois institutos, visto ser o poder discricionário, baseado puramente dentro de parâmetros legais, cabendo ao administrador uma opção, diferentemente do poder arbitrário, que extravasa a esfera legal, agindo contra ou mesmo fora do parâmetro legal.

A discricionariedade não é tampouco sinônimo de arbitrariedade, como bem refere AGUSTÍN GORDILLO, em seu Tratado de direito administrativo, quando aborda a defesa do usuário e do administrado, que nos atos de governo especificamente "en ciertos actos el Poder Ejecutivo tiene una potestad de índole discrecional, pues también está más que claro en el derecho administrativo que discricionariedad no es sinônimo de arbitrariedad; que la facultad discrecional tiene límites jurídicos que permitem controlar judicialmente el ejercicio de tal actividad'. ${ }^{77}$

74 MEIRELLES, op. cit., p. 127.

75 MELLO. Curso de direito..., p. 205.

76 TÁCITO. Poder de polícia..., p. 110.

77 GORDILLO, A. Tratado de derecho administrativo. La defensa del usuario y del administrado. 3. ed. Buenos Aires: Fundacion de Derecho Administrativo, t. 2, 1998, p. VIII-31. 
Como em qualquer outro ramo da Administração, há um limite conatural ao exercício discricional, de atingir uma finalidade legal. No caso do uso dos meios coativos, ligados diretamente às liberdades individuais, é necessário que a Administração os utilize com extrema cautela, "nunca se servindo de meios mais enérgicos que os necessários à obtenção do resultado pretendido pela lei", podendo ser responsabilizada por isso. É fundamental que haja proporcionalidade, ${ }^{78}$ entre a medida a ser adotada e a finalidade que se espera atingir. ${ }^{79}$

Essa proporcionalidade ou razoabilidade é um critério que serve para demarcar a discricionariedade frente à arbitrariedade, é dizer, com SALAVERRÍA, "la potestad discrecional consiste en elegir una entre un abanico de opciones razonables". E acrescenta: "es que admitem varias interpretaciones, pero al menos tienem de bueno que no permitem cualquier interpretación. Análogamente, suele suceder que, en una coyuntura dada, haya dos o más opciones alternativas socialmente razonables" ${ }^{80}$

Por fim, há que se referir com, TOMAS FERNANDEZ, que discricionariedade não é arbitrariedade, como insistem em afirmar as sentenças dos tribunais espanhóis, é dizer por um lado: " $<<$ Nunca es permitido confundir, pues aquello (lo discrecional) se halla o debe hallarse cubierto por motivaciones suficientes, discutibles o no, pero considerables em todo caso y no meramente de una calidad que lo hago inatacabl'. Já por outro lado, verifica-se "(lo arbitrario), o no tiene motivación respetable, sino pura y simplesmente - la conocida sit pro ratione voluntas o la que ofrece lo es tal que escudrinãndo su entranã denota, o poco esfuerzo de contrastación, su caráter reamente indefinible y su inautenticidad >> ", trazendo a motivação e a justificação como critérios de distinção entre a discricionariedade e a arbitrariedade..$^{81}$

Assim como não se pode confundir os institutos, visto estarem legalmente delimitados, não há que se utilizá-los tampouco como sinônimos.

\section{A NATUREZA JURÍDICA DO PODER DE POLÍCIA É DISCRICIONÁRIA?}

\subsection{Limites ao poder de polícia e à discricionariedade}

Antes de firmarmos uma posição quanto à natureza jurídica do poder de polícia, se ela é discricionária ou não, há que se considerar a importância fundamental diante dos casos concretos, das limitações do poder de polícia e da discricionariedade, visto serem motivos de discussão doutrinária.

78 MEDAUAR. Direito administrativo..., p. 394. Importante observação feita pela autora: "Autores franceses, espanhóis e alemães utilizam o termo proporcionalidade e autores argentinos e norteamericanos preferem o termo razoabilidade, para afirmarem que as medidas de limitação de direitos devem manter congruência com os motivos e fins que as justificam".

79 MELLO. Curso de direito..., p. 682.

80 SALAVERRÍA, op. cit., p. 42 e 54.

81 FERNANDEZ, T. R. De la arbitrariedad de la administracion. 2. ed. ampl. Madri: Civitas, 1997, p. 81-82. 
Num primeiro momento, há que se referir que os doutrinadores não são unânimes na classificação e extensão dos limites do poder de polícia. Podemos, contudo, referir como limites os direitos fundamentais, a legalidade dos meios e as regras de competência, forma, motivo e finalidade. Vale dizer que estas são regras comuns a todos os atos ${ }^{82}$ administrativos.

Pode o poder de polícia acarretar certas restrições ou disciplinar certos atos, referentes aos direitos fundamentais, declarados e assegurados que estão na nossa Constituição Federal, em benefício do interesse público, direitos estes que não podem ser suprimidos, devido clara previsão legal, sendo limitados, por fim, pelas regras de competência, da forma, do motivo e a finalidade, visando ao interesse público. ${ }^{83}$

Desta forma, o interesse social, em consonância com os direitos fundamentais assegurados aos indivíduos no art. $5^{\circ}$ da Carta Magna, num Estado Democrático, como o brasileiro, inspira-se em princípios de liberdade e em ideais solidários que demarcam os limites do poder de polícia administrativa.

Através das restrições às próprias atividades individuais, afetando a coletividade, cada indivíduo tem dado uma parcela de direitos à comunidade, sendo que o Estado é que vai retribuir "em segurança, ordem, higiene, sossego, moralidade e outros benefícios públicos, propiciadores do conforto individual e do bem-estar geral". Todavia, para que tais efetivações ocorram, utiliza o Estado um poder discricionário, próprio de poder de polícia administrativa, conferido pela norma geral, ficando ao critério do administrador o modo e condições da prática deste ato, vez que, se a autoridade ultrapassar esses limites legais, incidirá em abuso de poder, que pode ser corrigido pela via judiciária, ficando inclusive sujeito a invalidação, ${ }^{84}$ quando praticados com excesso ou desvio de poder. ${ }^{85}$

Refere MEIRELLES que esses limites, como condições de validade, que no ato de polícia são as mesmas do ato administrativo comum, é dizer: competência, finalidade, e forma são condições gerais de eficácia de qualquer ato, incluídos ainda a proporcionalidade da sanção e a legalidade dos meios usados pela administração, meios estes que devem ser "legítimos, humanos e compatíveis com a urgência e a necessidade

82 Pode se entender por ato administrativo o ato unilateral, que implica no uso de um poder jurídico do Estado, regido pelo Direito Administrativo e sujeito ao controle jurisdicional de legalidade.

Ato administrativo é ainda "o acto voluntário de um órgão da administração que, no exercício da função administrativa, e usando de um poder público, concretiza em comandos individualizados o comando contido abstractamente na norma jurídica" segundo PEREIRA, op. cit., p. 95.

83 MEDAUAR. Direito administrativo..., p. 396-397.

84 PEREIRA. Op. cit., p. 73-74. Não há no direito português "invalidade por vício de mérito, sendo exactamente coincidentes as noções de invalidade e de ilegalidade do acto administrativo. (...) A invalidade do acto administrativo se reduz à sua ilegalidade".

MEIRELLES, op. cit., p. 125-126. 
da medida adotada". ${ }^{86}$ Acresce ainda MUKAI os motivos determinantes ${ }^{87}$ e DI PIETRO o objeto. ${ }^{88}$

Também no direito espanhol, há referência às limitações ao poder de polícia, como refere LINARES, "el poder del Estado de derecho es él género y el de polícía una especie en cuanto potestad. Todas las limitaciones que rigen ara el Estado, cuando de algún modo incide en la libertad jurídica individual, valen para el poder de policía". Tais limites referem-se a "competência, formas, objeto, fin del acto. Razonabilidad. Esto vale tanto para la ley formal como para la material y los actos individuales de aplicación. La garantía de legalidad o legitimidad, en sentido amplio, es también una valla para el poder de policía". ${ }^{89}$

Assim como são referidos os limites ao exercício do poder de polícia, também têm sido elaboradas teorias para fixar limites ao exercício do poder discricionário, para que seja ampliada a apreciação pelo Judiciário. Sendo uma dessas teorias o desvio de poder, ou seja, quando a autoridade se utiliza de seu poder discricionário, com o objetivo de atingir fim contrário ao que fixou a lei. Outra teoria é a dos motivos, cujo ato será válido, apenas se for verdadeiro. ${ }^{90}$

Os atos administrativos, como verificado, podem ser controlados judicialmente, pelo Poder Judiciário, agora, há que se observar um aspecto fundamental, e para isso a distinção entre atos vinculados e discricionários é tão importante.

No que tange aos atos vinculados, não há restrição alguma, visto estarem todos os elementos estampados na lei, cabendo ao Judiciário apenas o exame legal, decretando sua nulidade somente se inexistir essa conformidade. Já no que tange aos atos discricionários, este controle é possível se observados os limites assegurados à Administração Pública. ${ }^{11}$

Noutra seara, há que se observar que essa tendência da doutrina, de querer ampliar o alcance da apreciação realizada pelo Judiciário, não pode ser uma invasão na esfera administrativa discricional, e traz DI PIETRO, "o que se procura é colocar essa discricionariedade em seus devidos limites, para distinguí-la da interpretação (apreciação que leva a uma única solução, sem interferência da vontade do intérprete) e impedir a

86 MEIRELLES, op. cit., p. 131-132.

87 MUKAI, op. cit., p. 99-100. “A competência está ligada ao cumprimento do princípio da especialidade administrativa; a finalidade, ao princípio da finalidade administrativa; a forma, ao princípio da impessoalidade; e a proporcionalidade, ao da proporcionalidade dos meios aos fins; a legalidade dos meios empregados está ligada a este último princípio e ao da legalidade, pois, em tema de polícia, segundo BONNARD, la fin justifique pas tous les moyens".

88 DI PIETRO. Direito administrativo..., p. 99-100. São regras a serem observadas pela polícia administrativa, com o fim de não eliminar os direitos individuais: necessidade, proporcionalidade e eficácia.

89 LINARES, op. cit., p. 430-431.

90 DI PIETRO. Direito administrativo..., p. 181.

91 Ibid., p. 180 
arbitrariedade que a Administração Pública pratica sob o pretexto de agir discricionariamente". ${ }^{22}$

A discricionariedade infundada, assim como a arbitrariedade são incompatíveis com o Estado de direito, significando que deve prevalecer sempre um "sincronismo entre o poder de polícia legítimo do Estado e os interesses supremos do cidadão, sempre resguardados pela Constituição no sentido de não admitir qualquer lesão de direito. Não pode, em absoluto, o poder de polícia produzir lesão de direito, e, quando eventualmente isto ocorre, a reparação compete ao Poder Judiciário, repondo o desejado status quo ante". ${ }^{93}$

Entende SANCHEZ MÓRON que o controle judicial da discricionariedade administrativa é um controle de natureza estritamente jurídica, "que sólo puede realizarse com parámetros jurídicos y que no puede abocar a outro tipo de decisión que no sea la de imponer el respecto de los límetes jurídicos de la acción administrativa". Esse controle é puramente dentro da legalidade e submissão da atuação administrativa aos fins que a justificam. ${ }^{94}$

Como informamos, o Poder Judiciário será acionado quando ocorrer uma lesão a um direito. E, dentro deste contexto, cabe destacar a importância que representa a motivação das decisões administrativas discricionais. ${ }^{95}$ Assim, as teses têm um denominador comum, prefigurando a possibilidade de eleger entre uma as opções possíveis. É o que bem demonstra SALAVERRÍA, que somente num contexto concreto "se puede determinar si las opciones posibles son realmente varias y, por tanto, sólo entonces cobrará sentido referirse al ejercicio de uma potestad discrecional. Su presencia, entonces, no puede verificarse a priori com la mera lectura de una disposición legislativa, por mucho que ésta deje en manos de la Administración un virtual espacio de maniobra". ${ }^{96}$

Num Estado Democrático de Direito como o brasileiro, valores como segurança, igualdade, justiça, bem-estar, entre outros, são dirigidos diretamente aos magistrados, legisladores, administradores públicos, e, como bem observa DI PIETRO, os valores atuam como "limites à discricionariedade administrativa, os quais, se ultrapassados, configuram ato ilícito da Administração, passível de revisão pelo Poder Judiciário. A discricionariedade administrativa - como poder jurídico que é - não é limitada só pela

92 Ibid., p. 182.

93 LUZ, op. cit., p. 61.

94 MÓRON, op. cit., p. 155-156.

95 SALAVERRÍA, op. cit., p. 14-15. Sustenta quatro teses: "1. Com o termo discricionariedade denotamse fenômenos heterogêneos (...) a que estão atribuídos a destinatários distintos; 2 . Uma previsão jurídiconormativa, que contenha conceitos indeterminados; 3 . A chamada discricionariedade técnica está regulada por normas jurídicas; e 4. (...) o ordenamento jurídico Espanhol não permite excluir o controle de fundo da decisão, com o que, aos juízes compete não só anular mas sim inclusive substituir as decisões que os órgãos administrativos houverem adotado no marco da precitada discricionariedade técnica". 
lei, em sentido formal, mas pela idéia de justiça, com todos os valores que lhe são inerentes, declarados a partir do preâmbulo da Constituição". ${ }^{97}$

\subsection{A natureza jurídica do poder de polícia é discricionária ou não?}

Passa-se à análise do que se considera fundamental nessa pesquisa, quanto à natureza jurídica do próprio poder de polícia, informando que ela não é discricionária; todavia, o que pode ser discricionário são os atos, que ora podem ser discricionários e ora vinculados, dependendo do que dispõe a lei, (grifamos alguns aspectos). Veja-se:

JOSÉ CRETELLA JUNIOR, seguindo as orientações de RAFAEL BIELSA, aduz que o poder de polícia sempre existiu no Estado, qualquer que tenha sido sua natureza jurídica, quer tenha sido em relação aos fins, quer como caráter amplo de política, como instituição administrativa, jurídica, ou social, visto a idéia de Estado não se separar da de polícia, pois o poder de polícia é faculdade discricionária. ${ }^{98}$

Adverte YUSSEF SAID CAHALI que o poder de polícia é discricionário, "encontrando barreiras nos direitos dos cidadãos, nas prerrogativas individuais e nas liberdades públicas, cabendo ao Poder Judiciário decidir se essas barreiras foram, ou não, ultrapassadas". ${ }^{99}$

RUY CIRNE LIMA, quando alude à verdadeira natureza da polícia, referindose ao poder de polícia, diz estar caracterizada no conceito apresentado por AURELINO LEAL, cujo "<<poder de polícia se exerce por proibições e por ordens $>>$ ". No direito antigo, polícia significava arbítrio. Hoje, num conceito moderno de polícia, "admite-se às autoridades administrativas, nesse terreno, maior ou menor discreção; recusa-selhes, no entanto, todo e qualquer arbítrio". ${ }^{100}$

No mesmo sentido, CAIO TÁCITO, afirma ser o poder de polícia eminentemente um poder discricionário, estando sua noção ligada ao conceito de legalidade, ${ }^{101}$ trazendo

97 DI PIETRO. Discricionariedade..., p. 34.

98 CRETELLA JR., op. cit., p. 44 e 54.

99 CAHALI, Y. S. Responsabilidade civil do estado. São Paulo: Malheiros, 1996, p. 503-504. Exemplificando: "Hipótese em que a propriedade privada foi posta em perigo, respondendo a Administração Pública pelas perdas e danos. O Distrito Federal, não sendo proprietário das terras, nem tendo sua posse, tolhido está de promover ação possessória ou reivindicatória. Não pode o Poder Público opor-se ao cerceamento de área particular exposta a invasores, em nome da proteção ambiental, e por isso deve responder pelos prejuízos suportados pelo judiciário". TJDF, $2^{\mathrm{a}}$ T., Ap. 23.513, 06.12.1993, DJU III, 29.03.1994, p. 3.196 e Repertório IOB de Jurisprudência 1/7.416.

100 LIMA, op. cit., p. 110. "Ora, na administração do Estado moderno, tudo se move dentro do direito; tôda atividade administrativa se encontra vinculada a um fim impessoal tutelado pelo direito (...). A maior dose de discreção possível não envolve, destarte, arbítrio nenhum".

101 TÁCITO, C. O princípio de legalidade: Ponto e contraponto. In: Revista de Direito Administrativo. Rio de Janeiro, n. 206, out./dez. 1996, p. 3. "A noção do poder de polícia, em seu lineamento tradicional, se fixou na garantia da segurança, da tranqüilidade e da salubridade públicas, contra os abusos individuais. E, embora ampliado como contenção de direitos sociais e coletivos, representa, em síntese, a aplicação do poder discricionário como processo de disciplinar, em benefício do interesse público adequado, o exercício de direitos e liberdades fundamentais". 
inclusive que no campo do poder de polícia há uma larga margem de discricionariedade. Assim o poder de polícia funciona como um limite à liberdade e à autoridade, inclusive como "medida de validade do ato de polícia que a limitação imposta à liberdade ou ao direito individual, como ao direito coletivo ou difuso, repouse em critério adequado de proporcionalidade e de razoabilidade". ${ }^{102}$

Também no entender de SEABRA FAGUNDES, o poder de polícia é uma faculdade discricionária do Estado, visando à proteção tanto da ordem, paz e bemestar social, e no uso desse poder a autoridade administrativa impõe restrições relacionadas à liberdade das profissões, de comércio, reunião, entre outras. ${ }^{103}$

Como a discricionariedade é a livre escolha por parte da Administração, tanto da oportunidade como da conveniência, de praticar o poder de polícia, aplicando sanções e usando dos meios adequados para o atingir a finalidade perquerida no interesse público, pode-se dizer que o ato de polícia administrativa, estando dentro desses limites legais e nessa faixa de opção, tem-se a discricionariedade como legítima. Assim, leciona MEIRELLES que "no uso da liberdade legal de valoração das atividades policiadas e na graduação das sanções aplicáveis aos infratores é que reside a discricionariedade do poder de polícia, mas mesmo assim a sanção deve guardar correspondência e proporcionalidade com a infração". ${ }^{104}$

Contudo, o ato de polícia, que em princípio é discricionário, será vinculado caso a norma legal estabeleça tanto o modo, como a forma de efetivação, pois o poder de polícia possui faculdade discricionária. ${ }^{105}$

Para FERNANDO ANDRADE DE OLIVEIRA, o poder de polícia "como todo poder, constrange as pessoas naturais e jurídicas, mas deriva da lei, que o legitima e o delimita. Nem mesmo constitui um poder essencialmente discricionário, como tem sido afirmado. As medidas de aplicação geral e preventiva, da polícia administrativa, que constituem os seus regulamentos, são adotadas com certa dose de discricionariedade quanto à sua oportunidade e conveniência, e mesmo quanto ao seu objeto". Assim, pode a administração exercer discricionariamente o seu poder de polícia, se autorizada por lei e se visar ao interesse público. ${ }^{106}$

102 TÁCITO. Poder de polícia..., p. 270.

103 FAGUNDES, M. S. O controle dos atos administrativos pelo poder judiciário. São Paulo: Saraiva, 1984 , p. 291

104 MEIRELLES, op. cit., p. 127. Como exemplo, cita: "se a lei permite a apreensão de mercadorias deterioradas e sua inutilização pela autoridade sanitária, esta pode apreender e inutilizar os gêneros imprestáveis para a alimentação, a seu juízo; mas se a autoridade é incompetente para a prática do ato, ou se o praticou sem a prévia comprovação da imprestabilidade dos gêneros para sua destinação, ou se interditou a venda fora dos casos legais, sua conduta torna-se arbitrária e poderá ser impedida ou invalidada pela justiça".

105 Ibid., p. 127.

106 OLIVEIRA, F. op. cit., p. 15. "O que ocorre, por exemplo, na apreciação de pedido de porte de arma, ou se uso especial de bem público afetado ao uso comum (atos de autorização ou permissão). Mas são vinculados os de licença de construção, de localização e funcionamento de estabelecimento industrial, comercial, hospitalar, etc., ou para o exercício de certas profissões e, ainda, os de admissão em escola 
Como visto, há hipóteses em que cabe à Administração sua manifestação discricionária, verificando a conveniência e oportunidade, concordando com a prática de certos atos vedados aos particulares de uma forma geral. E há hipóteses em que cabe uma manifestação vinculada à lei.

Contrariamente às posições apresentadas, temos CELSO ANTÔNIO BANDEIRA DE MELLO, que diz que geralmente tem se afirmado que o poder de polícia é atividade discricionária. Ora, se a expressão for utilizada no seu sentido amplo, "abrangendo as leis condicionadoras da liberdade e da propriedade em proveito do bem-estar coletivo, a assertiva é válida desde que considere a ação do Legislativo como gozando de tal atributo". Agora, o que se tem tentado fazer é caracterizar como sendo discricionário o próprio poder de polícia administrativa, o que não é procedente. ${ }^{107}$

No Estado de Direito não há um poder discricionário fruível pela Administração Pública. "Há, isto sim, atos em que a Administração Pública pode manifestar competência discricionária e atos a respeito dos quais a atuação administrativa é totalmente vinculada. Poder discricionário abrangendo toda uma classe ou ramo de atuação administrativa é coisa que não existe". É portanto inexato afirmar que o poder de polícia é discricionário, o que há, sim, é que a "polícia administrativa se expressa ora através de atos no exercício de competência discricionária, ora através de atos vinculados". ${ }^{108}$

No mesmo sentido, EROS GRAU tem como equivocada a alusão do poder de polícia como "faculdade discricionária" pois a Administração não tem funções discricionárias, e, sim, atos passíveis de exercício discricionário e atos cuja atividade é vinculada na sua totalidade. ${ }^{109}$

Nesta mesma linha de raciocínio temos ODETE MEDAUAR, que enfatiza "nem sempre a medida relativa ao poder de polícia decorre do exercício do poder discricionário. Às vezes, a Administração somente dá concreção a dispositivos de lei, por exemplo: do Código de Obras e Edificações, fiscaliza seu cumprimento e impõe as respectivas sanções, sem margem de escolha". Assim, se expressam ora através de atos praticados no exercício de competência discricionária, a exemplo das autorizações e ora vinculados, a exemplo das licenças. ${ }^{110}$

pública - todos necessariamente expedidos desde que satisfaçam as exigências legais. São igualmente vinculados os atos que determinem obrigações de fazer: a conservação de prédios ou a reparação dos edifícios em ruína, o levantamento de muros, etc. E mais: os de aplicação de sanções administrativas aos infratores da lei".

107 MELLO. Curso de direito..., p. 674.

108 Ibid., p. 672 e 675 . "No caso específico da polícia administrativa é fácil demonstrá-lo. Basta considerar que, enquanto as autorizações, atos típicos da polícia administrativa, são expedidas no uso de competência exercitável discricionariamente, as licenças, igualmente expressões típicas dela, são atos vinculados, consoante pacífico entendimento da doutrina".

109 GRAU, op. cit., p. 95

110 MEDAUAR. Direito administrativo..., p. 394-396. A "autorização apresenta-se como ato administrativo discricionário e precário, pelo qual a Administração consente no exercício de certa atividade; portanto, inexiste direito subjetivo à atividade; No âmbito do poder de polícia, diz respeito ao exercício de atividades cujo livre exercício pode, em muitos casos, constituir perigo ou dano para a coletividade, 
Note-se: Não se pode afirmar que o poder de polícia seja discricionário, pois não o é, às vezes expressa-se por atos discricionários e às vezes por atos vinculados. Assim, o próprio poder de polícia administrativa não é discricionário.

A discricionariedade está presente em grande parte das medidas de polícia, mas nem sempre isso acontece, por vezes a lei deixa uma margem de liberdade de apreciação quanto a certos elementos, a exemplo do motivo ou objeto, mesmo porque não pode o legislador prever todas as hipóteses de atuação de polícia. O que leva a Administração a ter que decidir, nos casos concretos, o melhor momento, o meio mais adequado, a sanção cabível, em tais circunstâncias, e nesses casos o poder de polícia será discricionário. Já em outras hipóteses a lei estabelece desde logo, que frente a certos requisitos, terá a Administração que adotar uma solução já estabelecida anteriormente na lei, sem essa possibilidade de opção, e, nesses casos, o poder será vinculado. ${ }^{111}$

Outra também não é a compreensão no direito argentino, trazido por JUAN FRANCISCO LINARES, pois o "poder de polícia no es forzosamente poder discrecional". ${ }^{112}$

No mesmo sentido, TOMAS FERNANDEZ traz que "En materia de medidas de polícia, reducto clásico de la discricionalidad y por ello campo tradicionalmente propicio a un control jurisdicional restrictivo, son ya franca mayoría las sentencias que realizan com toda natiuralidad un control plenario". Como exemplo refere: outorga e cancelamento de licença para o uso de armas, autorizações de abertura de bares e salas de bingo e denegações de renovação de permissões de trabalho quando estrangeiro. ${ }^{113}$

Contudo, podemos afirmar que o próprio poder de polícia não é discricionário, como tem-se inadvertidamente suposto.

\section{CONSIDERAÇÕES FINAIS}

A reflexão que se faz frente a esta importante temática da natureza jurídica do poder de polícia é no sentido de referir as abordagens e posições da doutrina e legislação, tecendo agora algumas observações relevantes.

Temos noções do poder de polícia, das mais variadas, elaboradas ao longo dos anos, todavia, esse poder atua como um limite ao exercício de um direito individual, disciplinando e restringindo direitos e liberdades individuais, visando unicamente o interesse público, beneficiando a coletividade, prevenindo ou reprimindo atos violadores.

mas que não é oportuno impedir de modo absoluto; por isso, a autoridade administrativa tem a faculdade de examinar caso a caso, as circunstâncias de fato em que o exercício pode desenvolver-se, a fim de apreciar a conveniência e oportunidade da outorga". A "licença é ato administrativo vinculado pelo qual o poder público, verificando que o interessado atendeu a todas as exigências legais, possibilita-lhe a realização de atividades ou de fatos materiais, vedados sem tal apreciação".

111 DI PIETRO. Direito administrativo..., p. 97-98.

112 LINARES, op. cit., p. 495.

113 FERNANDEZ, op. cit., p. 70-72. 
Mesmo que tenhamos adotado uma tradução do direito americano, e muito embora sigamos orientações do direito europeu, temos que ter presente que o poder de polícia deve ser utilizado na sistemática brasileira como uma faculdade que possui a Administração Pública como restrição ou condição de bens, direitos e atividades, em detrimento da coletividade.

No Brasil, por força da conveniência, o termo poder de polícia vige entre nós, e não há porque substituí-lo por outro termo, necessária sim, uma maior compreensão de seu significado, abrangência, limitações e utilização.

Assim, temos o caráter preventivo da polícia administrativa, objetivando impedir ações anti-sociais e o caráter repressivo da polícia judiciária, objetivando punir infratores.

A polícia administrativa tem importância fundamental na Administração Pública, vez que, regida pelo direito administrativo, vai inferir sempre sobre algum comportamento administrativo relacionado a bens, direitos ou atividades, destacandose entre os poderes administrativos justamente porque exerce tais atividades, que afetam a sociedade.

Por outro lado, verificamos que a discricionariedade desde sua origem e evolução, no decorrer dos tempos, foi e é fundamental no direito administrativo, e isto pode ser visto a partir das noções apresentadas pela doutrina e jurisprudência pátria e estrangeira, visando a perfectibilizar o fim último, de interesse público, dentro da legalidade, e dentro dum aspecto mais amplo de justiça.

Dessa forma, temos os atos discricionários, praticados pela Administração com certa margem de liberdade, podendo avaliar ou decidir conforme um critério que seja mais conveniente e oportuno, mesmo que adstrito à lei, temos também, os atos vinculados, como um único comportamento possível, frente a uma situação legalmente prevista, sem interferência subjetiva.

Por outra via, não se pode confundir os institutos, da discricionariedade e da arbitrariedade, visto estarem legalmente delimitados, e não há que se utilizá-los tampouco como sinônimos, pois falamos em discricionariedade quando estamos diante de uma liberdade de agir, dentro da lei, e falamos em arbitrariedade quando estamos diante de uma ação, que esteja fora ou além da legalidade.

Verificamos ainda que os doutrinadores não são unânimes, nem na classificação e extensão dos limites do poder de polícia, nem dos limites do poder discricionário.

Entendemos assim, com DI PIETRO, que, num Estado Democrático de Direito como o brasileiro, valores como segurança, igualdade, justiça, bem-estar, entre outros, são dirigidos diretamente aos magistrados, legisladores, administradores públicos, sendo que tais valores limitam a discricionariedade administrativa, vez que, se forem além desses limites, ocorrerá um ilícito passível de ser revisto pelo Judiciário.

Consideramos, portanto, que a natureza jurídica do próprio poder de polícia não é discricionária, mas o que pode ser discricionário são os atos, por vezes vinculados e por vezes discricionários. 
Concordamos, ao final, com BANDEIRA DE MELLO, que no Estado de Direito não há um poder discricionário fruível pela Administração Pública, mas "atos em que a Administração Pública pode manifestar competência discricionária e atos a respeito dos quais a atuação administrativa é totalmente vinculada. Poder discricionário abrangendo toda uma classe ou ramo de atuação administrativa é coisa que não existe". É portanto inexato afirmar que o poder de polícia é discricionário, o que há, sim, é que a "polícia administrativa se expressa ora através de atos no exercício de competência discricionária, ora através de atos vinculados". ${ }^{114}$

\section{REFERÊNCIAS BIBLIOGRÁFICAS}

CANOTILHO, José Joaquim Gomes. Direito constitucional. 3. ed. reimp. Coimbra: Almedina, 1999.

CONSTITUIÇÃO DA REPÚBLICA FEDERATIVA DO BRASIL. 27 ed. atual. e ampl. São Paulo: Saraiva, 2001.

CÓDIGO TRIBUTÁRIO NACIONAL. São Paulo: Saraiva, 2001.

CRETELLA JUNIOR, José. Direito administrativo do Brasil. Poder de polícia. São Paulo: Revista dos Tribunais, v. IV, 1961.

DE PLÁCIDO E SILVA. Vocabulário jurídico. Rio de Janeiro: Forense, 1999.

DI PIETRO, Maria Sylvia Zanella. Direito administrativo. 4. ed. São Paulo: Atlas, 2000. . Discricionariedade administrativa na Constituição de 1988. São Paulo: Atlas, 1991.

FAGUNDES, Miguel Seabra. O controle dos atos administrativos pelo poder judiciário. São Paulo: Saraiva, 1984.

FERNANDEZ, Tomas R. De la arbitrariedad de la administracion. 2. ed. ampl. Madri: Civitas, 1997.

FIGUEIREDO, Lúcia Valle. Curso de direito administrativo. 4. ed. rev. ampl. e atual. São Paulo: Malheiros, 2000.

FRANÇA, Vladimir da Rocha. Vinculação e discricionariedade nos atos administrativos. In:

Revista de Direito Administrativo. Rio de Janeiro: FVG-Renovar, n. 222, out./dez. 2000.

FREITAS, Juarez. Estudos de direito administrativo. 2. ed. rev. e atual. São Paulo: Malheiros, 1997.

GRAU, Eros Roberto. Poder de polícia: Função administrativa e princípio da legalidade: O chamado "direito alternativo" In: Revista Trimestral de Direito Público, n. 1.

GORDILLO, Agustín. Princípios gerais de direito público. São Paulo: Revista dos Tribunais, 1977.

Tratado de derecho administrativo. La defensa del usuario y del administrado. 3. ed. Buenos Aires: Fundacion de Derecho Administrativo, t. 2, 1998.

LIMA, Rui Cirne. Princípios de direito administrativo. 5. ed. São Paulo: Revista dos Tribunais, 1982.

LINARES, Juan Francisco. Derecho administrativo. Buenos Aires: Astrea, 1986.

LUZ, Egberto Maia. Direito administrativo contemporâneo. Curitiba: Juruá, 2000. 
MEDAUAR, Odete. Direito administrativo moderno. 4. ed. rev. atual. e ampl. São Paulo: Revista dos Tribunais, 2000.

. Poder de Polícia. In: Revista de Direito Administrativo, Rio de Janeiro: Renovar-FGV, n. 199, p. 89-96, jan./mar. 1995.

MEIRELLES, Hely Lopes. Direito administrativo brasileiro. 25. ed. São Paulo: Malheiros, 2000.

. Direito municipal brasileiro. 10. ed. São Paulo: Malheiros, 1998.

MELLO, Celso Antônio Bandeira de. Curso de direito administrativo. 12. ed. rev. atual. e ampl. São Paulo: Malheiros, 2000.

. Discricionariedade e controle jurisdicional. 2. ed. São Paulo: Malheiros, 1993.

MÓRON, Miguel Sánches. Discrecionalidad administrativa y control judicial. Madrid: Editorial Tecnos, 1994.

MUKAI, Toschio. Direito administrativo sistematizado. São Paulo: Saraiva, 1999.

OLIVEIRA, Fernando Andrade de. A Administração Pública na Constituição de 1988 ( $1^{\mathrm{a}}$ parte). In: Revista de Direito Administrativo. Rio de Janeiro: Renovar, 184, abr./jun. 1991, p. 1-24.

OLIVEIRA, Odília Ferreira da Luz. Implicações da Distinção entre Poder de Polícia e Serviço Público. In: Revista de Direito Público, n. 74.

PEREIRA, André Gonçalves. Erro e ilegalidade no acto administrativo. Coleção Jurídica Portuguesa, n. 22, São Paulo: Ática, [19-].

QUEIRÓ, Afonso Rodrigues. Os limites do poder discricionário das autoridades administrativas. In: Estudos de Direito Administrativo I. Atlântida: Coimbra, 1967, p. 7-19.

SALAVERRÍA, Juam Igartua. Discricionalidad técnica, motivación y control jurisdiccional. Madrid: Civitas, 1998.

SUNDFELD, Carlos Ari. Fundamentos de direito público. São Paulo: Malheiros, 1992.

TÁCITO, Caio. O princípio de legalidade: Ponto e contraponto. In: Revista de Direito Administrativo. Rio de Janeiro, n. 206, p. 1-8, out./dez. 1996. 1994. . Poder de polícia. In: Boletim de Direito Municipal - BDM, jun. 1995, Pernambuco,

TAWIL, Guido Santiago. Administración y Justicia. Alcance del control judicial de la actividad administrativa. I. Buenos Aires: Ediciones Depalma, 1993. 